\title{
PERBANDINGAN MODEL PEMBELAJARAN BERBASIS MASALAH DAN MODEL PEMBELAJARAN PENEMUAN TERHADAP HASIL BELAJAR SISWA PADA MATERI PERSAMAAN GARIS LURUS DI KELAS VIII SMP NEGERI 10 KENDARI
}

\author{
La Ode Ahmad ${ }^{\text {I) }}$ Muchtar Ibrahim ${ }^{2)}$, La Arapu ${ }^{3)}$ \\ ${ }^{1)}$ Alumni Jurusan Pendidikan Matematika, ${ }^{2,3)}$ Dosen Jurusan Pendidikan Matematika \\ FKIP Universitas Halu Oleo. Email: ahmadlakudo23@gmail.com
}

\begin{abstract}
Abstrak
Penelitian ini bertujuan untuk melihat perbedaan hasil belajar matematika antara siswa yang diajar menggunakan model Problem Based Learning dan siswa yang diajar menggunakan model Discovery Learning. Populasi penelitian adalah seluruh siswa kelas VIII SMP Negeri 10 Kendari yang terdiri dari 7 kelas paralel dengan jumlah siswa sebanyak 345 siswa. Teknik pengambilan sampel penelitian menggunakan teknik purposive sampling. Penentuan kelas Eksperimen I dan kelas Eksperimen II dilakukan secara simple random sampling. Teknik pengumpulan data dilakukan dengan pemberian instrumen penelitian berupa lembar observasi dan tes hasil belajar matematika berbentuk tes uraian/essay. Teknik analisis data menggunakan statistik deskriptif dan statistik inferensial. Berdasarkan hasil persyaratan analisis diperoleh data hasil belajar matematika siswa kedua kelas berdistribusi normal, memiliki varians yang homogen dan berdasarkan hasil pengujian hipotesis "Tidak terdapat perbedaan yang signifikan antara rerata hasil belajar matematika siswa yang diajar menggunakan model Problem Based Learning dan siswa yang diajar menggunakan model Discovery Learning".
\end{abstract}

Kata Kunci: Problem based learning, discovery learning, hasil belajar matematika.

\section{COMPARISON OF PROBLEM BASED LEARNING MODEL AND DISCOVERY LEARNING MODEL TO STUDENT'S MATHEMATICS LEARNING OUTCOMES ON STRAIGHT LINE EQUATION MATTER AT EIGHTH GRADE SMP NEGERI 10 KENDARI}

\begin{abstract}
This research aim to look the difference of mathematics learning outcomes between students were teached with Problem Based Learning model and students were teached with Discovery Learning model. The population was all eighth grade students of SMP Negeri 10 Kendari consists of 7 parallel classroom which amount to 345 students. The sample taken with purposive sampling technique. Determination of Experiment Class I and Experiment Class II was done according to simple random sampling. Technique of data collection was done by giving research instrument that are observation and essay mathematics learning outcomes test. Technique of data analysis were using descriptive statistic and inferential statistic. Obtained data of student's mathematics learning outcomes is normal distribution, owned homogene variant and according to result of hypothesis testing "There are not significant difference of mathematics learning outcomes average between students were teached with Problem Based Learning model and students were teached with Discovery Learning model".
\end{abstract}

Keywords: problem based learning, discovery learning, mathematics learning outcomes. 


\section{Pendahuluan}

Pendidikan pada hakikatnya merupakan usaha untuk mencari agar mengetahui informasi yang dibutuhkan dan berguna bagi kehidupan. Pendidikan juga merupakan proses belajar untuk dapat melakukan sesuatu (learning to do). Proses belajar menghasilkan perubahan dalam ranah kognitif, peningkatan kopetensi, serta pemilihan dan penerimaan secara sadar terhadap nilai, sikap, penghargaan, perasaan, serta kemauan untuk berbuat atau merespon suatu stimulus. Pendidikan membekali manusia tidak sekedar untuk mengetahui, tetapi lebih jauh terampil berbuat atau mengerjakan sesuatu sehingga menghasilkan sesuatu yang bermakna bagi kehidupan.

Kualitas pendidikan di negara kita Indonesia sampai saat ini masih rendah bahkan mengalami kemerosotan. Berdasarkan data dalam Education For All (EFA) Global Monitoring Report yang dikeluarkan Organisasi Pendidikan, Ilmu Pengetahuan, dan Kebudayaan Perserikatan Bangsa-Bangsa (UNESCO) bahwa kualitas pendidikan Indonesia berada di peringkat ke- 64 di seluruh dunia. Dalam laporan terbaru program pembangunan $\mathrm{PBB}$ tahun 2013 bahwa Indonesia menempati posisi 121 dari 185 negara dalam Indeks Pembangunan Manusia (IPM) dengan angka 0,629. Dengan angka itu Indonesia tertinggal dari dua negara tetangga ASEAN yaitu Malaysia (peringkat 64) dan Singapura (peringkat 18).

Matematika merupakan salah satu mata pelajaran yang dipelajari disekolah, bahkan matematika adalah satu-satunya mata pelajaran yang di pelajari secara eksplisit mulai dari sekolah dasar sampai perguruan tinggi. Hal itu terjadi karena matematika merupakan ilmu pengetahuan dengan pola berpikir yang sistematis, kritis, logis, cermat, dan konsisten, serta menuntut daya kretif dan inovatif, dimana dengan pola berpikir demikian dapat menunjang peserta didik untuk mempelajari ilmu pengetahuan lain, sehingga tidak berlebihan jika dikatakan bahwa matematika adalah ratu dari ilmu pengetahuan sebagaimana yang diungkapkan oleh Carl Friedrich Gauss seorang ahli matematika Jerman (Ismadi, 2011: 1).

Matematika sebagai ratu atau ibunya ilmu pengetahuan dimaksudkan bahwa matematika merupakan sumber dari ilmu yang lain dan berkembangnya tidak tergantung pada ilmu tertentu. Dengan kata lain, banyak ilmuilmu yang penemuannya dan pengembangannya bergantung pada matematika. Sebagaimana diungkap oleh Sriyanto (2007: 16) bahwa kemajuan sains dan teknologi yang begitu pesat dewasa ini tidak terlepas dari peranan matematika. Boleh dikatakan bahwa landasan utama sains dan teknologi adalah matematika. Jadi matematika memiliki peran yang cukup penting terhadap kemajuan ilmu pengetahuan.

Kenyataan di SMP Negri10 Kendari, saat peneliti melakukan interview (wawancara) terhadap beberapa guru mata pelajaran matematika kelas VIII SMP Negri 10 Kendari pada tanggal 14 April 2015 bahwa saat ini siswa-siswi SMP Negeri 10 Kendari belum menunjukan keinginan yang tinggi untuk belajar matematika, siswa pasif dan tidak berani bertanya serta tidak mampu menyampaikan ideide mereka dalam proses pembelajaran.

Berdasarkan uraian diatas maka peneliti berniat dan terdorong untuk melakukan penelitian dengan judul "Perbandingan Model Pembelajaran Berbasis Masalah (Problem Based Lerning) dan Model Pembelajaran Penemuan (Discovery Learning) Terhadap Hasil Belajar Siswa Pada Materi Persamaan Garis Lurus di Kelas VIII SMP Negri 10 Kendari.

Menurut Gagne dalam bukunya The Conditioning of Learning mengemukakan bahwa belajar adalah perubahan yang terjadi dalam kemampuan manusia setelah belajar secara terus-menerus, bukan hanya disebabkan oleh proses pertumbuhan saja, melainkan belajar di pengaruhi oleh faktor dari luar diri dan faktor dari dalam diri serta keduanya saling berinteraksi (Raymond, 2009: 27).

Prayitno (2009: 203) mengemukakan pengertian belajar yang berbeda menurutnya istilah perubahan tingkah laku sebagai proses dan hasil belajar agaknya kurang memberikan penjelasan dengan demikian konsep yang lebih operasional perlu di berikan untuk pengertian tentang belajar. Secara operasional dapat di kemukakan bahwa belajar adalah upaya menguasai sesuatu yang baru. Konsep ini mengandung dua hal pokok yaitu (a) usaha untuk menguasai, dan (b) sesuatu yang baru. Usaha untuk menguasai merupakan aktifitas belajar yang sesungguhnya dan sesuatu yang baru merupakan sesuatu yang di peroleh dari aktifitas belajar itu. 
Teori belajar atau konsep belajar adalah suatu konsep pemikiran yang dirumuskan mengenai bagaimana proses belajar itu terjadi. Menurut Notoatmodjo (1997) teori belajar dapat dikelompokkan menjadi dua kelompok yaitu:

a. Teori yang hanya memperhitungkan faktor yang datang dari luar individu (Faktor Eksternal) dikenal dengan teori stimulus dan respon.

b. Teori yang hanya memperhatikan faktor yang datang dari dalam diri individu (Faktor Internal), maupun yang berasal dari luar diri individu (Faktor Eksternal), yang dikenal dengan teori transformasi. Sunaryo (2002: 165-166).

Menurut Ahmadi dan Supriyono (1991: 121) pengertian belajar jika dilihat secara psikologi adalah: Suatu proses perubahan didalam tingkah laku sebagai hasil interaksi dengan lingkunganya dalam memenuhi kebutuhan hidupnya. Dengan perkataan lain, belajar adalah suatu proses usaha yang dilakukan individu untuk memperoleh suatu perubahan tingkah laku yang baru secara keseluruhan sebagai hasil pengalaman individu itu sendiri.

Sardiman

(2006:

20-21)

mengemukakan, dalam pengertian luas, belajar dapat diartikan sebagai kegiatan psiko-fisik menuju ke perkembangan pribadi seutuhnya. Kemudian dalam arti sempit, belajar dimaksudkan sebagai usaha penguasaan materi ilmu pengetahuan yang merupakan sebagian kegiatan menuju terbentuknya kepribadian seutuhnya. Dalam hal ini yang dimaksud dengan belajar berarti usaha mengubah tingkah laku. Perubahan itu tidak hanya berkaitan dengan penambahan ilmu pengetahuan, tetapi juga berbentuk kecakapan, keterampilan, sikap, pengertian, harga diri, minat, watak, serta penyesuaian diri. Terlebih lagi dalam mempelajari matematika yang struktur ilmunya berjenjang dari yang paling sederhana sampai yang paling kompleks, dari yang konkrit samapai ke abstrak.

Dalam ilmu pengetahuan, matematika berperan penting dan melayani sedemikian banyak cabang-cabang ilmu sehingga seorang ahli matematika yang berasal dari Amerika,Skotlandia, Erik Temple Bell menamakan matematika sebagai Ratu dan Abdi ilmu pengetahuan.(Silvia: 148). Selain itu menurut Nasution (Dalam Supatmono, 2009: 8) mengatakan bahwa matematika merupakan ilmu struktur, urutan (order), dan hubungan yang meliputi dasar-dasar perhitungan,pengukuran, dan penggambaran bentuk objek. Ilmu ini melibatkan logika dan kalkulasi kuantitatif, dan pengembangannya telah meningkatkan derajat idealisasi dan abstraksi subjeknya.

Menurut Brownell (dalam Suryadi, 2001: 7), matematika merupakan suatu sistem yang terdiri atas ide, prinsip, dan proses sehingga keterkaitan antar aspek-aspek tersebut harus dibangun dengan penekanan bukan pada memori atau hafalan melainkan pada aspek penalaran atau intelegensi anak. Jika matematika disajiakan kepada anak dengan cara yang demikian, maka konsep yang dipelajari menjadi punya arti; dipahami sebagai suatu disiplin yang terurut, terstruktur, dan memiliki keterkaitan satu dengan lainnya; serta diperoleh melalui proses pemecahan masalah yang bervariasi.

James (dalam Suherman 2001: 16) menyatakan bahwa matematika adalah konsep ilmu tentang logika mengenai bentuk, susunan, besaran, dan konsep-konsep yang berhubungan sat dengan yang lainnya dengan jumlah banyak yang terjadi kedalam tiga bidang yaitu aljabar, analisis, dan geometri. Namun The Gie (1999: 23), mengutip pendapat seorang ahli matematika bernama Charles Edwar Jeaneret yang mengatakan:'Mathematics is the majestic structure by man to grant himcomprehension of the universe, yang artinya matematika adalah struktur besar yang di bangun oleh manusia untuk memberikan pemahaman mengenai jagat raya".

Menurut (Sudjana, 2011: 22) hasil belajar adalah kemampuan-kemampuan yang dimiliki siswa setelah menerima pengalaman belajarnya. Kemampuan-kemampuan yang dimiliki tiap siswa tentu berbeda karena pengalaman belajar yang dialami antar siswa yang satu dengan yang lainnya juga berbeda. Aspek perubahan itu mengacu kepada taksonomi tujuan pengajaran yang dikembangkan oleh Blom, Simpson, dan Harrow yang mencakup tiga aspek yaitu aspek kognitif, afektif, dan psikomotorik (Winkel dalam Purwanto, 2008: 45).

Klasifikasi hasil belajar menurut Bloom dalam Suprijono (2009: 6) secara garis besar membagi garis besar membagi tiga ranah,yakni ranah kognitif, ranah afektif, dan ranah psikomotrik. 
1. Ranah Psikomotorik, berkenaan dengan hasil belajar intelektual.

2. Ranah afektif, berkenaan dengan sikap.

3. Ranah Psikomotorik, berkenaan dengan hasil belajar keterampilan dan kemampuan bertindak.

Dimyanti dan Mudjiono (2002: 150151) menjelaskan bahwa hasil belajar merupakan hal yang dapat dipandang dari dua sisi siswa dan dari sisi guru. Dari sisi siswa, hasil belajar merupakan tingkat perkembanan mental yang lebih baik bila dibandingkan pada saat sebelum belajar. Sedangkan Oemar (2006: 30) menegaskan bahwa hasil belajar adalah bila seseorang telah belajar akan terjadi perubahan tingkah laku pada orang tersebut, misalnya dari tidak tahu menjadi tahu, dan dari tidak mengerti menjadi mengerti.

Pendapat-pendapat di atas dapat disimpulkan bahwa pengertian hasil belajar adalah kemampuan yang dimiliki siswa setelah ia menerima pengalaman belajarnya. Hasil belajar mempunyai peranan penting dalam proses pembelajaran. Proses penilaian terhadap hasil belajar dapat memberikan informasi kepada guru tentang kemajuan siswa dalam upaya mencapai tujuan-tujuan belajarnya melalui kegiatan belajar. Selanjutnya dari informasi tersebut guru dapat menyusun dan membina kegiatan-kegiatan siswa lebih lanjut, baik untuk keseluruhan kelas maupun individu. Apabila dicapai kualitas pembelajaran yang lebih baik maka akan dicapai pula hasil belajar yang baik. Pengertian hasil belajar dalam hal ini adalah kemampuan-kemampuan yang dimiliki siswa setelah ia melaksanakan pengalaman belajarnya (Sudjana, 2003: 22)

Menurut Gagne (dalam Abidin, 2011: 8) bahwa hasil belajar matematika adalah kemampuan-kemampuan yang dimiliki siswa setelah ia menerima pengalaman belajar matematikanya atau dapat dikatakan bahwa hasil belajar matematika adalah perubahan tingkah laku dalam diri siswa, yang diamati dan diukur dalam bentuk perubahan pengetahuan, tingkah laku, sikap dan keterampilan setelah mempelajari matematika. Perubahan tersebut diartikan sebagai terjadinya peningkatan dan pengembangan ke arah yang lebih baik dari sebelumnya.

Definisi di atas yakni tentang belajar, hasil belajar, dan matematika serta pengertian hasil belajar matematika yang di didefinisikan oleh Gagne (dalam Abidin, 2011: 8) maka peneliti dapat menarik kesimpulan bahwa hasil belajar matematika merupakan kemampuan yang dimiliki siswa setelah ia menerima pengalaman belajarnya yang membentuk suatu perubahan pengetahuan, tingkah laku, sikap dan keterampilan setelah mempelajari matematika serta menjadikannya sebagai tolak ukur atau patokan yang menentukan tingkat keberhasilan siswa dalam mengetahui dan memahami suatu materi pelajaran matematika setelah mengalami pengalaman belajar yang diukur melalui tes atau tolak ukur lainnya.

Ridwan (2014: 50-51) mengatakan bahwa model pembelajaran dengan pendekatan saintifik pada umumnya merupakan kegiatan pengamatan atau observasi yang dibutuhkan untuk perumusan hipotesis atau mengumpulkan data. Pendekatan ini pada umumnya juga dilandasi dengan pemaparan data yang diperoleh melalui pengamatan atau percobaan.

Menurut Yunus (2014: 125) model pembelajaran saintifik merupakan model pembelajaran yang menuntut siswa beraktifitas sebagaimana ahli sains. Model pembelajaran saintifik dapat dikatakan sebagai yang.memandu siswa untuk memecahkan masalah melalui kegiatan perencanaan yang matang, pengumpulan data yang cermat, dan analisis data yang teliti untuk mengahasilkan sebuah simpulan. Namun lain halnya dengan pandangan Barringer, et al (2010) dalam Yunus (2014: 125) mengatakan bahwa model pembelajaran saintifik merupakan pembelajaran yang menuntut siswa untuk berpikir secara sistematis dan kritis dalam upaya memecahkan masalah yang penyelesaiannya tidak mudah dilihat.

Menurut Yunus (2014: 129) bahwa model pembelajaran saintifik memiliki karakteristik khusus dalam penerapannya. Karakteristik tersebut antara lain sebagai berikut:

1. Objektif, artinya pembelajaran senantiasa dilakukan atas objek tertentu dan siswa dibiasakan memberikan penilaian secara objektif terhadap objek tertentu.

2. Faktual artinya pembelajaran artinya senantiasa dilakukan terhadap masalahmaslah faktual yang terjadi di sekitar siswa sehingga siswa di biasakan untuk menemukan fakta yang dapat di pertanggungjawabkan kebenarannya. 
3. Sistematis artinya pembelajaran dilakukan atas tahapan belajar yang sistematis dan tahapan belajar ini berfungsi sebagai panduan pelaksanaan pembelajaran.

4. Bermetode artinya dilaksanakan berdasarkan metode pembelajaran ilmiah tertentu yang sudah teruji ke efektifannya.

5. Cermat dan tepat artinya pembelajaran yang dilakukan untuk membina kecermatan dan ketepatan siswa dalam mengkaji sebuah fenomena atau objek belajar tertentu.

6. Logis artinya pembelajaran senantiasa menngangkat hal yang masuk akal.

7. Aktual yakni bahwa pembelajaran senantiasa melibatkan konteks kehidupan anak sebagai sumber belajar yang bermakna.

8. Disinterestid artinya pembelajaran harus dilakukan dengan tidak memihak melainkan benar-benar didasarkan atas capaian belajar siswa yang sebenarnya.

9. Unsupported opinion artinya pembelajaran tidak dilakukan untuk menumbuhkan pendapat atau opini yang tidak di sertai dengan bukti-bukti nyata.

10. Ferifikatif artinya hasil belajar yang diperoleh siswa dapat diferifikasi kebenarannya dalam arti diknfirmasikan, di refisi dan diulang dengan cara yang sama atau berbeda.

Menurut Tan (dalam Rusman 2010: 229) bahwa model pembelajaran berbasis masalah merupakan inovasi dalam pembelajaran, karena kemampuan berpikir siswa betul-betul dioptimalkan melalui proses kerja kelompok atau tim yang sistematis sehingga siswa dapat memperdayakan, mengasah, menguji, dan mengembangkan kemampuan berpikirnya secara berkesinambungan.

\begin{tabular}{crcr}
\multicolumn{2}{c}{ Pembelajaran } & berbasis & masalah \\
merupakan suatu & pendekatan & dalam
\end{tabular} pembelajaran dimana siswa mengerjakan permasalahan yang otentik dengan maksud untuk menyusun pengetahuan mereka sendiri, mengembangkan inkuiri dan keterampilan berpikir tingkat lebih tinggi, mengembangkan kemandirian dan kepercayaan diri, hal ini diungkapkan Arends (dalam Trianto 2007: 68).

Berdasarkan pendapat para ahli di atas maka dapat di simpulkan bahwa model pembelajaran berbasis masalah adalah suatu proses pendewasaan, kemandirian dan kedisiplinan dalam mencoba untuk berinovasi, serta merupakan model pembelajaran yang menjadikan peserta didik untuk berpikir dengan teliti yang penyampaiannya di awali dengan permasalahan, mengajukan pertanyaanpertanyaan, memfasilitasi penyelidikan, dan membuka dialog. Selanjutnya siswa menyelesaikan masalah tesebut untuk menemukan pengetahuan baru dalam peembelajaran.

Menurut Ridwan (2014: 134) bahwa karakteristik model Pembelajaran Berbasis Masalah sebagai berikut:

1. Belajar dimulai dengan mengkaji suatu masalah

2. Permasalahan berbasis pada situasi dunia nyata yang kompleks.

3. Siswa bekerja berkelompok.

4. Beberapa informasi yang dibutuhkan untuk menyelesaikan permasalahan tidak diberikan terlebih dahulu.

5. Siswa mengidentifikasi, menemukan dan menemukan sumber daya yang sesuai.

6. Belajar secara aktif, terintegrasi, kumulatif, dan terhubung.

Berdasarkan uraian tersebut tampak jelas bahwa pembelajaran dengan model pembelajaran berbasis masalah dimulai oleh adanya masalah (dapat dimunculkan oleh siswa atau guru), kemudian siswa memperdalam pengetahuannya tentang apa yang mereka telah ketahui dan apa yang mereka perlu ketahui untuk memecahkan masalah tersebut. Siswa dapat memilih masalah yang dianggap menarik untuk dipecahkan sehingga mereka terdorong berperan aktif dalam belajar.

Menurut Jacobsen (2009: 210) bahwa model pembelajaran penemuan (Discovery Learning) adalah pembelajaran yang menjadikan guru akan lebih sedikit dalam menjelaskan sehingga siswa lebih aktif dalam pembelajaran secara kognitif, mendorong pembelajaran dan motivasi. Senada dengan Slavin (2011: 11) menyatakan bahwa keunggulan model Discovery Learning yaitu membangkitkan keingintahuan siswa dan memotivasi mereka untuk terus bekerja dalam menemukan jawaban, siswa juga mempelajari kemampuan penyelesaian soal dan pemikiran kritis secara mandiri karena mereka harus menganalisis dan memanipulasi data. Hal tersebut juga diperkuat oleh pendapat Illahi (2012:34) yang menyatakan bahwa Discovery Learning merupakan model yang melibatkan siswa secara langsung dalam kegiatan belajar 
mengajar, sehingga siswa mampu menggunakan proses mentalnya untuk menemukan konsep pengetahuan yang dipelajarinya.

Beberapa pendapat para ahli di atas dapat ditarik kesimpulan bahwa model pembelajaran penemuan (Discovery Learning) adalah kegiatan belajar yang melibatkan siswa secara langsung dan lebih kreatif menciptakan situasi yang dapat membuat peserta didik untuk belajar lebih aktif menemukan pengetahuannya sendiri.

Tahap-tahap Model Pembelajaran Penemuan (Discovery Learning). Cara mengajar dengan metode penemuan menempuh langkahlangkah sebagai berikut: (1) Adanya masalah yang akan dipecahkan. (2) Sesuai dengan tingkat perkembangan kognitif peserta didik. (3) Konsep atau prinsip yang harus ditemukan oleh peserta didik melalui kegiatan tersebut perlu dikemukakan dan ditulis secara jelas. (4) Harus tersedia alat dan bahan yang diperlukan. (5) Susunan kelas diatur sedemikian rupa sehingga memudahkan terlibatnya arus bebas pikiran peserta didik dalam kegiatan belajar mengajar. (6) Guru Harus memberikan jawaban dengan tepat dari data yang diperlukan peserta didik. (Mulyasa, 2008: 110).

\section{Metode}

Penelitian ini akan dilaksanakan di kelas VIII SMP Negeri 10 Kendari pada Semester Ganjil Tahun Ajaran 2015/2016.

Populasi dalam penelitian ini adalah siswa kelas VIII SMP Negeri 10 Kendari tahun ajaran 2015/2016 yang terdiri dari 7 kelas

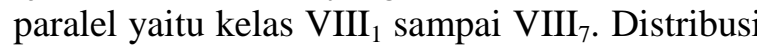
siswa kelas VIII SMP Negeri 10 Kendari dapat dilihat pada table 1.1 berikut:

Tabel 1.

Distribusi Siswa Kelas VIII SMP Negeri 10 Kendari

Semester Genap Tahun Pelajaran 2015/2016

\begin{tabular}{|c|c|c|}
\hline No. & Kelas & Jumlah Siswa \\
\hline 1. & VIII $_{1}$ & 34 \\
\hline 2. & VIII $_{2}$ & 33 \\
\hline 3. & VIII $_{3}$ & 33 \\
\hline 4. & VIII $_{4}$ & 33 \\
\hline 5. & VIII $_{5}$ & 33 \\
\hline 6. & VIII $_{6}$ & 33 \\
\hline 7. & $\mathrm{VIII}_{7}$ & 35 \\
\hline \multicolumn{2}{|c|}{$\mathrm{JUMLAH}^{2}$} & 234 \\
\hline
\end{tabular}

Sampel pada penelitian ini dipilih dengan menggunakan teknik Purposive Sampling. Teknik purposive adalah teknik penentuan sampel dengan kriteria atau pertimbangan tertentu. Sampel penelitian dipilih dengan cara melihat nilai rata-rata ujian

semester kedua mata pelajaran matematika yaitu mempunyai nilai rata-rata yang sama dan selain itu, pertimbangannya adalah sampel yang di ambil diajar oleh guru yang sama, sehingga kelas yang terpilih adalah kelas VIII.5 dan VIII.6.

Tabel 2.

Data Siswa Kelas Eksperimen I dan Kelas Eksperimen II

\begin{tabular}{|c|c|c|c|c|}
\hline \multirow{2}{*}{ KELAS } & \multicolumn{3}{|c|}{ JUMLAH SISWA } & \multirow{2}{*}{ KETERANGAN } \\
\cline { 2 - 4 } & LAKI-LAKI & PEREMPUAN & JUMLAH & \\
\hline VIII $_{5}$ & 15 Orang & 14 Orang & 29 Orang & Kelas Eksperimen I \\
\hline VIII $_{6}$ & 17 Orang & 13 Orang & 30 Orang & Kelas Eksperimen II \\
\hline
\end{tabular}

Sumber: SMP Negeri 10 Kendari

Varibel yang digunakan dalam 1. Variabel bebas yaitu perlakuan berupa penelitian ini terdiri dari variabel bebas dan pembelajaran dengan menggunakan model variabel terikat, yaitu: pembelajaran berbasis masalah (Problem Based Learning) dan perlakuan dua berupa 
pengajaran dengan menggunakan model pemblajaran penemuan (Discoveri Learning)

2. Variabel terikat dlam penelitian ini yaitu hasil belajar matematika siswa yang diajar dengan menggunakan pembelajaran berbasis masalah (Problem Based Learning) dan hasil belajar matematika siswa yang diajar dengan menggunakan penemuan (Discovery Learning)

Desain penelitian yang digunakan adalah posttest group design yang digambarkan pada Tabel dibawah ini.

Tabel 3.

Desain Penelitian post-test group design

\begin{tabular}{|c|c|c|}
\hline Kelompok & Perlakuan & Post-test \\
\hline $\mathrm{E}_{1}$ & $\mathrm{X}_{1}$ & $\mathrm{O}_{1}$ \\
\hline $\mathrm{E}_{2}$ & $\mathrm{X}_{2}$ & $\mathrm{O}_{2}$ \\
\hline
\end{tabular}

(Sugiyono, 2011: 113)

Penlitian ini mempunyai dua instrumen, yaitu instrumen berupa lembar observasi dan instrumen tes hasil belajar siswa. Data mengenai proses pembelajaran pada kelas eksperimen satu $\left(\mathrm{E}_{1}\right)$ dan kelas eksperimen dua $\left(\mathrm{E}_{2}\right)$ diperoleh dari lembar observasi yang di isi oleh observer pada saat berlangsungnya proses belajar mengajar dalam tiga minggu, sedangkan data hasil belajar matematika diperoleh dari instrumen hasil belajar matematika yang diberikan kepada siswa pada kelas eksperimen satu $\left(E_{1}\right)$ dan eksperimen dua $\left(E_{2}\right)$ setelah proses pembelajaran pada materi persamaan garis lurus dalam penelitian ini. Instrumen tersebut memiliki kualitas yang sama, kemudian instrumen tersebut diselesaikan oleh siswa, selanjutnya instrument tersebut dikumpulkan oleh peneliti untuk diperiksa dan diberi skor dengan mengacu pada pedoman pensekoran instrumen hasil belajar matematika. Skor tersebut merupakan data hasil belajar matematika pada penelitian ini yang kemudian akan dianalisis.

Penelitian ini menggunakan dua teknik analisis data yitu anlisis deskriptif dan analisis inferensial. Analisis deskriptif digunakan untuk memperoleh data tentang aktivitas /partisipasi guru dan siswa. Analisis deskriptif juga dimaksudkan untuk mendeskripsikan hasil belajar matematika siswa melalui nilai rata-rata dari masing-masing kelas yang dibentuk oleh kelas yang diajar menggunakan model Problem Based Learning dengan pendekatan saintifik dan kelas yang diajar menggunakan model Discovery Learning dengan pendekatan saintifik. Analisis inferensial dimaksutkan untuk menguji hipotesis perbedaan rata-rata hasil belajar matematika siswa antara siswa yang diajar menggunakan model problem based lerarning dengan pendekatan saintifik dan siswa yang diajar menggunakan model Discovery Learning dengan pendekatan saintifik.

Berdasarkan hasil analisis uji normalitas dan uji homogenitas data hasil belajar matematika kelompok yaitu kelaseksperimen I yang diajar menggunakan model Problem Based Learning dengan pendekatan saintifik dan kelas eksperimen II yang diajar dengan menggunakan model Discovery Learning dengan pendekatan saintifik diperoleh data berdistribusi normal dan varians homogen.

\section{Hasil}

Hasil observasi pelaksanaan pembelajaran yang dilakukan guru menggunakan model Problem Based Learning dengan pendekatan saintifik dapat terlihat dalam tabel 4 berikut.

Tabel 4.

Rekapitulasi Pelaksanaan Pembelajaran Model Problem Based Learning dengan Pendekatan Saintik oleh Guru

\begin{tabular}{|c|c|c|c|}
\hline Pertemuan & Skor Total & Persentase $(\%)$ & Kategori \\
\hline I & 16 & 80,00 & Baik \\
\hline II & 18 & 90,00 & Sangat Baik \\
\hline III & 18 & 90,00 & Sangat Baik \\
\hline
\end{tabular}




\begin{tabular}{|c|c|c|c|}
\hline IV & 19 & 95,00 & Sangat Baik \\
\hline V & 20 & 100,00 & Sangat Baik \\
\hline VI & 20 & 100,00 & Sangat Baik \\
\hline Skor Max & 20 & & \\
\hline
\end{tabular}

Keberhasilan pengelolaan pembelajaran pada pertemuan pertama sudah dikatakan baik dengan tingkat keberhasilan 80,00\%, yang dimana pengelolaan pembelajaran pada pertemuan pertama sudah masuk dalam kriteria baik. Pelaksanaan pembelajaran pada pertemuan kedua mengalami peningkatan yang baik dibanding pada pertemuan pertama. Tingkat keberhasilan mencapai 90,00\% dengan kategori

Tabel 5.

Rekapitulasi Pelaksanaan Pembelajaran Model Discovery Learning dengan Pendekatan Saintik oleh Guru

\begin{tabular}{|c|c|c|c|}
\hline Pertemuan & Skor Total & Persentase $(\%)$ & Kategori \\
\hline I & 15 & 78,95 & Baik \\
\hline II & 17 & 89,47 & Sangat Baik \\
\hline III & 17 & 89,47 & Sangat Baik \\
\hline IV & 18 & 94,73 & Sangat Baik \\
\hline V & 19 & 100,00 & Sangat Baik \\
\hline VI & 19 & 100,00 & Sangat Baik \\
\hline Skor Max & 19 & & \\
\hline
\end{tabular}

Berdasarkan hasil observasi terhadap pelaksanaan pembelajaran matematika menggunakan model Discovery Learning dengan pendekatan saitifik oleh peneliti yang bertindak sebagai guru di kelas eksperimen II pada materi Persamaan Garis Lurus, keberhasilan pengelolaan pembelajaran pada pertemuan pertama dengan kategori baik dan tingkat keberhasilannya adalah $78,95 \%$, yang dimana pengelolaan pembelajaran pada pertemuan pertama sudah masuk dalam kriteria

Pelaksanaan pembelajaran pada pertemuan kedua mengalami peningkatan dibanding pertemuan pertama. Tingkat keberhasilan mencapai 89,47\% dengan kategori sangat baik yang dimana pengelolaan pembelajaran pada pertemuan kedua ini dikatakan efektif.

Hasil observasi aktivitas siswa dalam pelaksanaan pembelajaran menggunakan model Problem Based Learning dengan pendekatan Saintifik dapat terlihat dalam tabel 6 berikut. baik.

Tabel 6.

Rekapitulasi Keaktifan Siswa pada Pembelajaran Model Problem Based Learning dengan Pendekatan Saintik

\begin{tabular}{|c|c|c|c|}
\hline Pertemuan & Skor Total & Persentase (\%) & Kategori \\
\hline I & 6 & 42,86 & Tidak Baik \\
\hline II & 11 & 78,57 & Baik \\
\hline III & 12 & 85,71 & Baik \\
\hline IV & 13 & 92.86 & Sangat Baik \\
\hline V & 12 & 100.00 & Sangat Baik \\
\hline VI & 13 & 100.00 & Sangat Baik \\
\hline Skor Max & 14 & & \\
\hline
\end{tabular}


Berdasarkan hasil observasi aktivitas siswa dalam pelaksanaan pembelajaran matematika menggunakan model Problem Based Learning dengan pendekatan Saintifik di kelas eksperimen I pada materi Persamaan Garis Lurus, pada pertemuan pertama ketercapaian seluruh aspek yang diamati adalah $42,86 \%$, tergolong tidak baik namun persentase ini dikatakan tidak efektif. Keadaan ini disebabkan karena sebagian siswa masih dalam tahap penyesuaian dengan teman kelompok maupun dengan model pembelajaran yang baru diterapkan.

Pertemuan kedua sampai dengan pertemuan keenam, memperlihatkan ketercapaian aspek yang diamati berturut-turut adalah 78.57, 85.71, 92.86, 100.00 dan $100,00 \%$. Secara umum, ketercapaian keseluruhan aspek yang diamati pada pertemuan kedua sampai dengan pertemuan keenam mengalami peningkatan jika dibandingkan dengan pelaksanaan pada pertemuan pertama. Peningkatan yang terjadi pada pertemuan kedua sangat tinggi berkisar $35,71 \%$ dan terus mengalami peningkatan dari pertemuanpertemuan sebelumnya.

Hasil observasi aktivitas siswa dalam pelaksanaan pembelajaran menggunakan model Discovery Learning dengan pendekatan Saitifik dapat terlihat dalam tabel 7 berikut.

Tabel 7.

Rekapitulasi Keaktifan Siswa pada Pembelajaran Model Discovery Learning dengan Pendekatan Saintik

\begin{tabular}{|c|c|c|c|}
\hline Pertemuan & Skor Total & Persentase $(\%)$ & Kategori \\
\hline I & 5 & 38,46 & Tidak Baik \\
\hline II & 10 & 76,92 & Baik \\
\hline III & 11 & 84.62 & Sangat Baik \\
\hline IV & 12 & 92.31 & Sangat Baik \\
\hline V & 13 & 100.00 & Sangat Baik \\
\hline VI & 13 & 100.00 & Sangat Baik \\
\hline Skor Max & 13 & & \\
\hline
\end{tabular}

Berdasarkan hasil observasi aktivitas siswa dalam pelaksanaan pembelajaran matematika menggunakan model Discovery Learning dengan pendekatan Saintifik di kelas eksperimen II pada materi Persamaan Garis Lurus, pada pertemuan pertama ketercapaian seluruh aspek yang diamati adalah 38,46\%, tergolong cukup baik dan persentase ini tidak efektif. Keadaan ini disebabkan karena sebagian siswa masih dalam tahap penyesuaian dengan teman kelompok maupun dengan model pembelajaran yang baru diterapkan.

Pertemuan kedua sampai dengan pertemuan keenam, memperlihatkan ketercapaian aspek yang diamati berturut-turut adalah 76.92, 84.62, 92.31, 100.00, dan $100,00 \%$. Secara umum, ketercapaian keseluruhan aspek yang diamati pada pertemuan kedua sampai dengan pertemuan keenam mengalami peningkatan jika dibandingkan dengan pelaksanaan pada pertemuan pertama.

Berdasarkan hasil analisis deskriptif hasil belajar matematika siswa dari data posttest yang diperoleh setelah di terapkan model Problem Based Learning dengan pendekatan saintifik pada kelas ekperimen I dengan jumlah siswa 28 orang siswa dan model Discovery Learning dengan pendekatan saintifik pada kelas eksperimen II dengan jumlah siswa 30 orang siswa maka diperoleh data post-test hasil belajar matematika siswa kelas eksperimen I dan kelas eksperimen II yang disajikan pada tabel 8 berikut:

Tabel 8.

Deskriptif Post-Test Hasil Belajar Matematika

Siswa Kelas Eksperimen I dan Kelas Eksperimen II

\begin{tabular}{|c|c|c|}
\hline Statistic & Eksperimen I & Eksperimen II \\
\hline Mean & 76,0268 & 72,5000 \\
\hline
\end{tabular}




\begin{tabular}{|c|c|c|} 
Sample Variance & 150,701 & 134,591 \\
\hline Standard Deviation & 12,27602 & 11,60132 \\
\hline Median & 75,00 & 71,875 \\
\hline Mode & 75,00 & 71,25 \\
\hline Minimum & 47,50 & 43,75 \\
\hline Maximum & 97,50 & 97,50 \\
\hline
\end{tabular}

Berdasarkan hasil analisis deskriptif post-test pada tabel 8 diatas bahwa hasil belajar matematika siswa pada kelas eksperimen I diperoleh nilai rata-rata 76,03 (pembulatan sampai dua angka di belakang koma) dengan standar deviasi sebesar 12,276. Sedangkan untuk kelas eksperimen II diperoleh nilai rata-rata 72,5 (pembulatan sampai satu angka di belakang koma) dengan standar deviasi sebesar 11,601.

Adapun distribusi frekuensi nilai hasil belajar matematika siswa setiap kelas eksperimen dapat diketahui dengan melihat data kalisifikasi tingkat penguasaan materi siswa (Permendikbud No. 81A Tahun 2013) yang disajikan pada tabel 9 dan tabel 10 sebagai berikut:

Table 9.

Daftar Distribusi Frekuensi dan Klasifikasi Hasil Belajar Matematika Siswa Pada Kelas Ekperimen I

\begin{tabular}{|c|l|c|c|l|}
\hline NO & \multicolumn{1}{|c|}{ Nilai } & Tingkat Penguasaan Siswa & Frekuensi & Presentase \\
\hline 1 & $0,00 \leq \mathrm{Y} \leq 33,25$ & Kurang & 0 & 0 \\
\hline 2 & $33,25<\mathrm{Y} \leq 58,25$ & Cukup & 3 & 10,71 \\
\hline 3 & $58,25<\mathrm{Y} \leq 83,25$ & Baik & 16 & 57,14 \\
\hline 4 & $83,25<\mathrm{Y} \leq 100,00 \quad$ Sangat Baik & 9 & 32,14 \\
\hline \multicolumn{2}{|c|}{ Jumlah } & 28 & \\
\hline
\end{tabular}

Table 10.

Daftar Distribusi Frekuensi dan Klasifikasi Hasil Belajar Matematika Siswa Pada Kelas Ekperimen II

\begin{tabular}{|c|c|c|c|c|}
\hline $\mathrm{NO}$ & Nilai & Tingkat Penguasaan Siswa & Frekuensi & Presentase \\
\hline 1 & $0,00 \leq \mathrm{Y} \leq 33,25$ & Kurang & 0 & 0 \\
\hline 2 & $33,25<Y \leq 58,25$ & Cukup & 4 & 13,33 \\
\hline 3 & $58,25<\mathrm{Y} \leq 83,25$ & Baik & 21 & 70 \\
\hline 4 & $83,25<\mathrm{Y} \leq 100,00$ & Sangat Baik & 5 & 16,67 \\
\hline \multicolumn{3}{|c|}{ Jumlah } & 30 & \\
\hline
\end{tabular}

Gambar 2. Grafik Distribusi Frekuensi dan Klasifikasi

Hasil Belajar Matematika Siswa Pada Kelas Eksperimen II

Dari tabel 9 diatas, diketahui nilai pada kelas eksperimen I, klasifikasi tingkat penguasaan materi siswa tergolong "Baik", yakni pada interval 58,25 $<\mathrm{Y} \leq 83,25$ dengan jumlah siswa 16 orang dengan persentase sebesar 57,14\%. Sedangkan pada tabel 4.7, diketahui nilai pada kelas eksperimen II, klasifikasi tingkat penguasaan materi siswa juga tergolong "Baik" yakni pada interval 58,25 < Y $\leq 83,25$ dengan jumlah siswa 21 orang dengan persentase sebesar $70 \%$. Data selengkapnya dapat dilihat pada lampiran.

Apabila dilihat dari ketuntasan hasil belajar matematika siswa setiap kelas eksperimen, maka dapat dilihat pada tabel 11 berikut:

Tabel 11.

Ketuntasan Hasil Belajar Matematika Siswa Kelas Ekperimen I dan kelas Eksperimen II 


\begin{tabular}{|c|c|c|}
\hline Kelas Eksperimen & Tuntas & Presentase \\
\hline Eksperimesn I & 23 Orang Siswa & $82,14 \%$ \\
\hline Eksperimesn II & 24 Orang Siswa & $80 \%$ \\
\hline
\end{tabular}

Berdasarkan tabel 11 yaitu pada kelas eksperimen I diperoleh 23 orang siswa yang tuntas dengan presentase $82,14 \%$; ketercapaian ketuntasan belajar matematika siswa pada kondisi ini dapat dikatakan baik karena siswa yang tuntas mencapai lebih dari $75 \%$. Sedangkan ketuntasan belajar siswa pada kelas eksperimen II diperoleh 24 orang siswa yang tuntas dengan presentase $80 \%$; ketercapaian ketuntasan belajar matematika siswa pada kondisi ini juga dapat dikatakan baik karena siswa yang tuntas mencapai lebih dari $75 \%$. Data selengkapnya disajikan pada lampiran.

Uji normalitas digunakan untuk mengetahui apakah data hasil belajar matematika kedua kelas berdistribusi normal atau tidak. Untuk menguji apakah data berdistribusi normal atau tidak digunakan statistik uji normalitas dengan rumus Kolmogorov-Smirnov melalui SPSS 17. Hasilnya ditunjukkan pada tablel 12 berikut.

Tabel 12.

Hasil Analisis Statistik Uji Normalitas Data Hasil Belajar Matematika Siswa Pada Kelas Eksperimen I dan Kelas Eksperimen II

\begin{tabular}{|c|c|c|}
\hline Kelas Eksperimen & Asymp. Sig (2-tailed) & Keterangan \\
\hline Eksperimen I & 0,698 & Normal \\
\hline Eksperimen II & 0,126 & Normal \\
\hline
\end{tabular}

Uji homogenitas digunakan untuk mengetahui apakah data mempunyai varians yang sama (homogen) atau tidak. Hasil analisis Uji Homogenitas dengan menggunakan SPSS 17 diperoleh nilai signifikansi sebesar 0,549 lebih besar dari nilai $\alpha=0,05$ sehingga dapat didsimpulkan bahwa data post-test memiliki varians yang homogen. adalah:

Rumusan hipotesis statistik yang diuji

Keterangan :

$$
\mathrm{H}_{0}: \mu_{1}=\mu_{2} \text { lawannya } \mathrm{H}_{1}: \mu_{1} \neq \mu_{2}
$$

$\mu_{1}=$ Rerata hasil belajar matematika siswa yang diajar menggunakan model Problem Based Learning dengan pendekatan Saintifik.

$\mu_{2}=$ Rerata hasil belajar matematika siswa yang diajar menggunakan model Discovery Learning dengan pendekatan Saintifik.

Hipotesis yang diajukan :

$\mathrm{H}_{0}=$ Tidak terdapat perbedaan yang signifikan antara rerata hasil belajar matematika
Sumber: Data Diolah Dengan SPSS.17

siswa yang diajar menggunakan model Problem Based Learning dengan pendekatan Saintifik dan siswa yang diajar menggunakan model Discovery Learning dengan pendekatan Saintifik pada materi segiempat dan segitiga.

$\mathrm{H}_{1}=$ Terdapat perbedaan yang signifikan antara rerata hasil belajar matematika siswa yang diajar menggunakan model Problem Based Learning dengan pendekatan Saintifik dan siswa yang diajar menggunakan mode Discovery Learning dengan pendekatan Saintifik pada materi persamaan garis lurus.

Kriteria pengujian yang digunakan adalah jika nilai $\mathrm{t}_{\text {hitung }}<\mathrm{t}_{\text {tabel }}$, maka $\mathrm{H}_{0}$ diterima. Untuk lebih jelasnya hasil pengujian hipotesis data hasil belajar matematika siswa pada kelas eksperimen I dan kelas eksperimen II tersebut dapat dilihat pada table 13 berikut :

Tabel 13

Hasil Analisis Statistik Uji Hipotesis Data Hasil Belajar Matematika Siswa Pada Kelas Eksperimen I dan Kelas Eksperimen II

\begin{tabular}{|c|c|c|c|c|}
\hline Kelas Eksperimen & N & t_hitung & t_tabel & Keterangan \\
\hline Eksperimen I & 28 & \multirow{2}{*}{1,125} & \multirow{2}{*}{2,0042} & \multirow{2}{*}{$\mathrm{H}_{0}$ diterima } \\
\hline Eksperimen II & 30 & & & \\
\hline
\end{tabular}


Pada tabel 13 terlihat bahwa nilai $\mathrm{t}_{\text {hitung }}=$ $1,125<\mathrm{t}_{\text {tabel }}=2,0042$ (dengan interpolasi) maka $\mathrm{H}_{0}$ diterima. Dengan demikian, dapat disimpulkan bahwa tidak terdapat perbedaan yang signifikan antara rerata hasil belajar matematika siswa yang diajar mengunakan model PBL dengan pendekatan Saintifik dan siswa yang di ajar menggunakan model DL dengan pendekatan Saintifik pada materi persamaan garis lurus.

\section{Pembahasan}

Dalam penelitian ini terdapat dua kelas eksperimen, yaitu kelas eksperimen I diajar menggunakan model PBL dan kelas eksperimen II diajar menggunakan model DL.

Berdasarkan hasil analisis diketahui bahwa aktivitas siswa dalam pelaksanaan pembelajaran matematika menggunakan model Problem Based Learning dengan pendekatan Saintifik di kelas eksperimen I pada materi persaan garis lurus, pada pertemuan pertama ketercapaian seluruh aspek yang diamati adalah $42,86 \%$, tergolong tidak baik namun persentase ini dikatakan tidak efektif. Keadaan ini disebabkan karena sebagian siswa masih dalam tahap penyesuaian dengan teman kelompok maupun dengan model pembelajaran yang baru diterapkan.

Jika dilihat dari persentase ketercapaian aspek yang diamati dari pertemuan kedua sampai dengan pertemuan keenam memperlihatkan ketercapaian aspek yang diamati berturut-turut yaitu 78.57, 85.71, 92.86, 100.00, dan 100.00. Secara umum, ketercapaian keseluruhan aspek yang diamati mengalami peningkatan jika dibandingkan dengan pelaksanaan pada pertemuan pertama. Peningkatan yang terjadi pada pertemuan kedua sangat tinggi berkisar $35,71 \%$ dan terus mengalami peningkatan dari pertemuanpertemuan sebelumnya. Bahkan ketercapaian pada pertemuan kedua dan pertemuan ketiga tergolong baik dan pada pertemuan keempat sampai dengan pertemuan keenam tergolong sangat baik. Berdasarkan hasil analisis data aktivitas siswa diperoleh rata-rata persentase keaktifan siswa dalam proses pembelajaran menggunakan model Problem Based Learning dengan pendekatan Saintifik dari pertemuan pertama hingga pertemuan keenam mencapai $83,33 \%$.
Sedangkan hasil analisis aktivitas siswa dalam pelaksanaan pembelajaran matematika menggunakan model Discovery Learning dengan pendekatan Saintifik di kelas eksperimen II pada materi segiempat dan segitiga, pada pertemuan pertama ketercapaian seluruh aspek yang diamati adalah $38,46 \%$, tergolong tidak baik dan persentase ini dikatakan tidak efektif. Keadaan ini disebabkan karena sebagian siswa masih dalam tahap penyesuaian dengan teman kelompok maupun dengan model pembelajaran yang baru diterapkan.

Jika dilihat dari persentase ketercapaian aspek yang diamati dari pertemuan kedua sampai dengan keenam memperlihatkan ketercapaian aspek yang diamati berturut-turut yaitu 76.92, 84.62, 92.31, 100.00, dan 100.00. Secara umum, ketercapaian keseluruhan aspek yang diamati pada pertemuan kedua sampai dengan pertemuan ketujuh mengalami peningkatan jika dibandingkan dengan pelaksanaan pada pertemuan pertama. Peningkatan yang terjadi pada pertemuan kedua sangat tinggi berkisar $38,46 \%$ dan terus mengalami peningkatan dari pertemuanpertemuan sebelumnya. Bahkan ketercapaian pada pertemuan kedua dan pertemuan ketiga tergolong baik dan pada pertemuan keempat sampai dengan pertemuan keenam tergolong sangat baik. Berdasarkan hasil analisis data aktivitas siswa diperoleh rata-rata persentase keaktifan siswa dalam proses pembelajaran menggunakan Discovery Learning dengan pendekatan Saintifik dari pertemuan pertama hingga pertemuan keenam mencapai $82,05 \%$.

Distribusi data aktivitas kedua kelas eksperimen dalam penelitian ini dapat memberikan kita kesimpulan bahwa pembelajaran menggunakan model Problem Based Learning dan model Discovery Learning dengan pendekatan Saintifik dapat membuat siswa lebih berperan aktif menemukan solusi penyelesain masalah dalam proses pembelajaran. Hal tersebut dapat dilihat dari persentase rata-rata aktivitas siswa selama enam kali pertemuan dalam proses pembelajaran baik menggunakan model Problem Based Learning dengan pendekatan Saintifik maupun model Discovery Learning dengan pendekatan Saintifik mencapai nilai rata-rata lebih dari $75 \%$.

Berdasarkan analisis ketuntasan hasil belajar siswa pada kelas eksperimen I yang diajar menggunakan model Problem Based 
Learning dengan pendekatan saintifik diperoleh 23 orang siswa yang tuntas dengan presentase $82,14 \%$, dengan nilai rata-rata 76,026. Ketercapaian ketuntasan hasil belajar matematika siswa pada kelas eksperimen I ini dapat dikatakan baik karena siswa yang tuntas mencapai lebih dari $75 \%$. Sedangkan ketuntasan hasil belajar matematika siswa pada kelas eksperimen II diajar menggunakan model Discovery Learning dengan pendekatan saintifik diperoleh 24 orang siswa yang tuntas dengan presentase $80 \%$, dengan nilai rata-rata 72,5 . Ketercapaian ketuntasan hasil belajar matematika siswa pada kelas eksperimen II ini juga dapat dikatakan baik karena siswa yang tuntas mencapai lebih dari $75 \%$.

Distribusi hasil analisis data ketuntasan hasil belajar dilihat dari nilai post-test siswa pada kedua kelas eksperimen dalam penelitian ini, dapat memberikan kita kesimpulan bahwa ketuntasan hasil belajar matematika siswa yang diajar menggunakan model Problem Based Learning dan model Discovery Learning dengan pendekatan saintifik dapat dikatakan baik. Sehingga kedua model ini dikatakan efektif apabila dilihat dari ketuntasan hasil belajar yang diperoleh siswa. Hal ini dilihat dari persentase rata-rata hasil belajar yang tuntas dalam pembelajaran selama enam kali pertemuan baik yang menggunakan model Problem Based Learning dengan pendekatan Saintifik maupun model Discovery Learning dengan pendekatan Saintifik mencapai nilai rata-rata $\geq 75 \%$.

Berdasarkan hasil analisis data dengan menggunakan uji- $t$, diperoleh $t_{\text {hitung }}=1,125<$ $t_{\text {tabel }(0,05 ; 56)}=2,0042$, maka $\mathrm{H}_{0}$ diterima. Dengan demikian, dapat disimpulkan bahwa tidak terdapat perbedaan yang signifikan antara rerata hasil belajar matematika siswa yang diajar mengunakan model Problem Based Learning dengan pendekatan Saintifik dan siswa yang diajar menggunakan model Discovery Learning dengan pendekatan Saintifik pada materi persamaan garis lurus. Impilkasi dari hasil penelitian ini adalah bahwa model Problem Based Learning dan model Discovery Learning dengan pendekatan saintifik memberikan efek, jika dilihat dari sebelum dan sesudah perlakuan pada kedua kelas eksperimen, yang artinya memberikan pengaruh yang sama terhadap hasil belajar matematika siswa pada materi persamaan garis lurus.

\section{Simpulan dan Saran}

\section{Simpulan}

Berdasarkan hasil penelitian, dapat disimpulkan sebagai berikut:

1. Hasil belajar siswa yang diajar menggunakan model Problem Based Learning dengan pendekatan saintifik dapat dikatakan baik, hal ini ditunjukkan dengan nilai rata-rata yang diperoleh kelas eksperimen I sebesar 76,0268; standard deviasi sebesar 12,27602 dan variance sebesar 150,701.

2. Hasil belajar siswa yang diajar menggunakan model Discovery Learning dengan pendekatan saintifik dapat dikatakan cukup baik, hal ini ditunjukkan dengan nilai rata-rata yang diperoleh kelas eksperimen II sebesar 72,5000; standard deviasi sebesar 11,60132 dan variance sebesar 134,591.

3. Tidak terdapat perbedaan yang signifikan antara rerata hasil belajar matematika siswa yang diajar mengunakan model Problem Based Learning dengan pendekatan Saintifik dan siswa yang diajar menggunakan model Discovery Learning dengan pendekatan Saintifik pada materi persamaan garis lurus.

\section{Saran}

Berdasarkan simpulan di atas, saran yang dapat diberikan sebagai berikut:

1. Bagi para guru bidang study matematika sekiranya dapat menggunakan model-model pembelajaran yang direkomendasikan pada kurikulum 2013 dan dipandang sejalan dengan pendekatan saintifik salah satunya adalah model Problem Based Learning dan model Discovery Learning sebagai alternative tindakan yang baik untuk meningkatkan hasil belajar matematika siswa khususnya dalam materi persamaan garis lurus.

2. Bagi siswa hendaknya selalu berusaha memahami setiap materi ajar matematika khususnya persamaan garis lurus dengan tuntas dan berusaha mengingat materi yang telah dipelajari, mampu melihat kaitannya dengan materi lain karena hal ini akan mempengaruhi hasil belajar matematika siswa dalam mempelajari materi selanjutnya. 
3. Bagi peneliti selanjutnya hendaknya dapat meneruskan penelitian ini untuk mengungkap faktor-faktor lain yang mempengaruhi hasil belajar matematika siswa khususnya di SMP Negeri 10 Kendari.

\section{Daftar Pustaka}

Dimayati \& Mudjiono. (2002). Belajar dan Pembelajaran. Jakarta: PT. Rineka Cipta.

Ilahi, MT. (2012). Pembelajaran Discovery Strategy dan Mental Vocational Skill, Yogyakarta: Diva Press.

Sani A. Ridwan. (2014). Pembelajaran Saintifik dan Implementasi Kurikulum 2013. Jakarta: PT. Bui Aksara.

Simamora Raymond H. (2009). Buku Ajar Kependidikan Perawatan. Jakarta: EGC.

Suherman, Eman dan Winatapura. ( 2001). Strategi Belajar Mengajar Matematika. Jakarta: Depdikbut.

Sunaryo. ( 2002). Psikologi untuk keperawatan. Jakarta: EGC.

Supatmono. (2009). Matematika Asyik. Jakarta: Grasindo.
Suryadi, Didi. (2007). Ilmu dan Aplikasi pendidikan Bagian III. Jakarta: PT. IMTIMA.

Tampomas, Husein. (2007). Matematika Plus 1A. Jakarta: Ghalia Indonesia.

Http://Belajarpsikologi. Com/Macam-Macam Metode Pembelajaran ( Diakses Pada Tanggal 18 Desember 2014).

Http://Rujukanskripsi. Blogspot. Com/2013/06/Kajian Teori Hakikat Hasil Belajar. Html

( Diakses pada tanggal 19 Desember 2014).

Http://Www. Akademia. Edu/6644958/Model Pembelajaran Discovery Learning (Diakses pada Tanggal 28 Desember 2014)

Http://Www. Akademia. Edu/9702143/ Variabel Dimensi dan Indikator (Diakses pada Tanggal 19 Desember).

Http://Www. Slideshare. Net Interest Matematika 2011/P-Pt 12334656. Pembelajaran Matematika dengan Metode Discovery. (Diakses pada Tanggal 28 Desember2014). 